\title{
Protein aggregation containing beta-amyloid, alpha-synuclein and hyperphosphorylated tau in cultured cells of hippocampus, substantia nigra and locus coeruleus after rotenone exposure
}

\author{
Rodrigo S Chaves, Thaiany Q Melo, Stephanie A Martins, Merari FR Ferrari ${ }^{*}$
}

\begin{abstract}
Background: Protein aggregates containing alpha-synuclein, beta-amyloid and hyperphosphorylated tau are commonly found during neurodegenerative processes which is often accompanied by the impairment of mitochondrial complex I respiratory chain and dysfunction of cellular systems of protein degradation. In view of this, we aimed to develop an in vitro model to study protein aggregation associated to neurodegenerative diseases using cultured cells from hippocampus, locus coeruleus and substantia nigra of newborn Lewis rats exposed to 0.5 , 1, 10 and $25 \mathrm{nM}$ of rotenone, which is an agricultural pesticide, for 48 hours.

Results: We demonstrated that the proportion of cells in culture is approximately the same as found in the brain nuclei they were extracted from. Rotenone at $0.5 \mathrm{nM}$ was able to induce alpha-synuclein and beta amyloid aggregation, as well as increased hyperphosphorylation of tau, although high concentrations of this pesticide (over $1 \mathrm{nM}$ ) lead cells to death before protein aggregation. We also demonstrated that the $14 \mathrm{kDa}$ isoform of alphasynuclein is not present in newborn Lewis rats.
\end{abstract}

Conclusion: Rotenone exposure may lead to constitutive protein aggregation in vitro, which may be of relevance to study the mechanisms involved in idiopathic neurodegeneration.

\section{Background}

Intra and extracellular accumulation of protein aggregates distributed throughout the central nervous system are hallmarks of neurodegenerative diseases like Parkinson's (PD) and Alzheimer's (AD) [1] as well as are present in the senile brain [2].

Intracellular insoluble inclusions containing the alphasynuclein protein, called Lewy bodies are commonly found in the brainstem, cerebellum, hypothalamus and autonomic nervous system of patients with PD, Lewy Body dementia, multiple system atrophy and other synucleinopathies [3-7].

Extracellular deposition of beta-amyloid peptide, derived from the abnormal cleavage of amyloid precursor protein, and intracellular neurofibrillary tangles of

\footnotetext{
*Correspondence: merari@usp.br
Department of Neurology, School of Medicine, University of Sao Paulo, Sao
Paulo, Brazil

*Correspondence: merari@usp.br
Department of Neurology, School of Medicine, University of Sao Paulo, Sao
Paulo, Brazil

* Correspondence: merari@usp.br
Department of Neurology, School of Medicine, University of Sao Paulo, Sao
Paulo, Brazil
}

hyperphosphorylated tau protein are features of the hippocampus, cerebellum, locus coeruleus and cerebral cortex [8] of healthy elderly individuals [9] and patients with $\mathrm{AD}$ and other senile dementias [10].

Another common characteristic of neurodegenerative disorders is the impairment of mitochondrial complex I respiratory which may lead to in vivo protein aggregation [11].

In view of this, the present study aims to develop a method of in vitro aggregation of alpha-synuclein, hyperphosphorylated tau and beta-amyloid in cultured cells from the hippocampus, substantia nigra and locus coeruleus using treatment with rotenone, which is a natural pesticide and specific inhibitor of mitochondrial NADH dehydrogenase within complex I of the respiratory chain leading to increase in oxidative stress possibly mimicking what occurs during the ageing process $[12,13]$. The most characterized effects of rotenone is on mitochondrial complex I, however this compound is 
lipophilic being able to cross the cells membrane and to inhibit the proteasome [14], promote dysfunction in GAPDH [15] and interact also with glial cells [16].

\section{Methods}

All procedures were performed in accordance to the institutional committee for animal care of the School of Medicine, University of Sao Paulo (\#0659/08).

\section{Cell culture}

Methodology employed for cell culture was a modification of the previously described protocol [17]. Briefly, neonatal Lewis rats had their brains dissected and the areas containing hippocampus, locus coeruleus and substantia nigra were excised. After dissection, blood and epithelial cells were removed in sterile cold solution consisting of $\mathrm{NaCl} 120 \mathrm{mM}, \mathrm{KCl} 5 \mathrm{mM}, \mathrm{KH}_{2} \mathrm{PO}_{4} 1.2$ $\mathrm{mM}, \mathrm{MgSO}_{4} 1.2 \mathrm{mM}, \mathrm{NaHCO}_{3} 25 \mathrm{mM}$, glucose 13 $\mathrm{mM}, \mathrm{pH} 7.22$. Subsequently, the tissues were cut into small pieces using a scissors and incubated with $0.05 \%$ trypsin (Gibco) at $37^{\circ} \mathrm{C}$ for 40 minutes in a water bath kept under agitation. Then, trypsin inhibitor $(0.006 \%$, Gibco) was added and the cells were mechanically dissociated using a Pasteur pipette, after the total decoupling the cell solution was centrifuged at $300 \mathrm{~g}$ for 5 minutes. The supernatant was discarded and cells were resuspended in Neurobasal A medium (Gibco) supplemented with Glutamax (Gibco) $0.25 \mathrm{mM}, \mathrm{B} 27$ (Gibco) 2\%, L-Glutamine (Sigma) $0.25 \mathrm{mM}$ and Gentamicin (Gibco) $40 \mathrm{mg} / \mathrm{l}$.

Cells were plated into either 8-well glass slides or 35 $\mathrm{mm}$ petri dishes (Nunc), at the concentration of 1800 cels $/ \mathrm{mm}^{2}$. Plates were treated the day before with poly$\mathrm{D}^{\text {-lysine }} 10 \mu \mathrm{g} / \mathrm{ml}$ (Sigma), and with fetal bovine serum $10 \%$ (Gibco) for 2 hours before plating the cells to facilitate adhesion. Cultures were kept in a humidified incubator with $5 \% \mathrm{CO} 2$ at $37^{\circ} \mathrm{C}$ for nine days. Culture medium was changed three hours after plating the cells and every three days of cultivation.

\section{Cell culture characterization}

Cell cultures were washed in PBS, fixed in 50\% methanol and $50 \%$ acetone for 10 minutes at $-20^{\circ} \mathrm{C}$, permeabilized with PBS containing $0.2 \%$ Triton for 30 minutes at room temperature. Unspecific binding sites were blocked with PBS containing 2\% NGS (Vector Laboratories), $0.2 \%$ Triton and $4 \%$ bovine serum albumin (BSA, Sigma) for 30 minutes at room temperature.

Cells from substantia nigra and locus coeruleus were incubated with mouse polyclonal antibody against tyrosine hydroxylase $\left(1 / 3000\right.$, Sigma) for 24 hours at $4^{\circ} \mathrm{C}$, followed by incubation with anti-mouse immunoglobulin conjugated to FITC (Jackson, 1/120) for 45 minutes at room temperature protected from light. Hippocampal cultures were subjected to MAP2 immunolabeling $\left(1 / 1000\right.$, Sigma) also at $4{ }^{\circ} \mathrm{C}$ overnight followed by incubation with FITC-conjugated secondary antibody in order to identify the neurons present in cultures.

The slides were mounted with mounting medium containing DAPI (4',6-diamidino-2-phenylindole, Vector Laboratories) to visualize cell nuclei. Immunolabeled cells were analyzed using a fluorescence microscope (Zeiss) equipped with appropriated filters using a $40 \times$ lens. Quantification was done by comparing images taken of 16 fields of culture plate using filters to visualize the label generated by FITC and DAPI. Cell culture characterization was repeated twice.

\section{Exposure to Rotenone}

Rotenone (Sigma, USA) was prepared with DMSO (Sigma, USA) (stock solution of $1 \mathrm{mM}$ ) and diluted in culture medium applied to cell cultures from hippocampus, locus coeruleus and substantia nigra in concentrations of $0.5,1,10$ and $25 \mathrm{nM}$ for 48 hours. Control groups were exposed to less than $0.01 \%$ DMSO diluted in culture medium. Cells were then subjected to trypan blue staining in order to identify cell death; to immunocytochemistry for identification of protein aggregates containing hyperphosphorylated tau, alpha-synuclein and beta-amyloid; and protein extraction for western blot experiments.

\section{Analysis of cell death}

After exposure to rotenone, $10 \mu \mathrm{l}$ of trypan blue stain solution (Gibco) which stains in blue the cytoplasm of cells with damaged plasma membrane, were added to the culture medium of cells. Immediately after the addition of trypan blue, the cells were examined under a microscope (Olympus) using an objective of $40 \times(400 \times$ magnification) and photographed to detect stained cells.

\section{Identification of protein aggregates through immunocytochemistry}

Cell cultures were fixed as described above and incubated for 24 hours at $4^{\circ} \mathrm{C}$ with either a mouse polyclonal antiserum against alpha-synuclein (Abcam, 4D6, Ab1903), or rabbit polyclonal antiserum against hyperphosphorylated tau (Sigma, Ser 199/202, T6819) or beta amyloid peptide (Abcam, Ab14220), the three antibodies were diluted $1 / 1000$ in PBS containing $0.3 \%$ Triton X-100 (Sigma) and $0.5 \%$ BSA (Sigma). Cells were washed in PBS and incubated with biotinylated goat anti-rabbit or anti-mouse immunoglobulin both diluted 1/200 (Vector, USA) for 2 hours at room temperature. Cells were washed in PBS and incubated with an avidin-biotin peroxidase complex (both diluted 1/120, Vectastain, Vector) for 2 hours. Immunoreactivity was visualized after 10 minutes of reaction with 3-3'-diaminobenzidine tetrahydrochloride 
(DAB, Sigma) as a chromogen and $\mathrm{H}_{2} \mathrm{O}_{2}(0.01 \%$, v/v, Sigma).

The occupied area $\left(\mu \mathrm{m}^{2}\right)$ of beta amyloid peptide immunoreactivity in the hippocampus cultures was calculated by means of a KS 400 image analyzer (Kontron, Zeiss, Germany) linked to a CCD 72 camera (Dage; MTI, Michigan City, Ind, USA) mounted on a Zeiss microscope (40× objective). Nine randomly chosen fields were considered for the quantification. The procedures have been described in detail elsewhere [18].

\section{Western blot analysis of protein aggregation}

Cultured cells were homogenized in PBS, pH 7.4, containing $1 \%$ NP40, $0.5 \%$ sodium deoxycholate, $1 \%$ SDS, $1 \mathrm{mM}$ EDTA, $1 \mathrm{mM}$ EGTA and 1\% protease inhibitor cocktail (Sigma). After centrifugation at $14000 \mathrm{rpm}$ for 20 minutes, the resulting supernatant was fractionated by SDS-PAGE ( $10 \mu \mathrm{g}$ of protein/lane) using a $12 \%$ tris$\mathrm{HCl}$ gel at $100 \mathrm{~V}$ for $1 \mathrm{~h}$. Proteins were transferred to nitrocellulose membrane for $1 \mathrm{~h}$ at $100 \mathrm{~V}$.

Blots were incubated in blocking solution containing $5 \%$ milk/TBS-T during $1 \mathrm{~h}$ at room temperature followed by incubation with primary antibodies against alpha-synuclein (Abcam, 4D6, Ab1903) or hyperphosphorylated tau (Sigma, Ser 199/202, T6819) both were diluted $1 / 1000$ in solution containing $3 \%$ milk/TBS-T, overnight at $4^{\circ} \mathrm{C}$.

Horseradish peroxidase-conjugated secondary antibody incubations were performed at room temperature for $1 \mathrm{~h}$ with antibody anti-mouse 1/6000 (Amersham) or anti-rabbit 1/10000 (Amersham).

Development was done after 5-minute incubation with enhanced chemiluminescence reagent (Millipore) and exposure of membranes to ECL sensitive films (Hyperfilm ECL, Amersham Biosciences). After development, blots were incubated with anti-beta-actin antibody 1/1000 (Santa cruz, C4, sc-47778) during $1 \mathrm{~h}$ at room temperature, followed by horseradish peroxidase conjugated secondary antibody anti-mouse (Amersham) diluted 1/6000 for 1 hour also at room temperature and developed as previously described.

Density normalization was done by dividing the density of the bands relative to proteins of interest by beta-actin value. Films were quantified by optical densitometry using a system of image analysis (Imaging Research Inc., Canada, model M4/SK/ALU).

All the analyses were made using protein samples from control and treated cells that were fractionated in a same gel and transferred to a single membrane which was incubated with the antibody solution.

The presence of alpha-synuclein isoforms was confirmed in neonate and adult (6 months old) Wistar and Lewis rats. This was performed because the isoform of $14 \mathrm{kDa}$ did not appear in cultured cells from Lewis newborn rats. To this end, rats were euthanized and had their brains excised instantly to protein extraction of substantia nigra which was subjected to the same western blot method described previously for cell culture. In addition to the antibody from Abcam, an immunoglobulin against alfa-synuclein from Santa Cruz Biotechnology (1/500; cat. 7011R) was employed to confirm the pattern of isoforms present in neonates and adults. An assay of adsorption was performed by adding specific blocking peptide (1/100, Santa Cruz; cat. 7011P) to the solution containing the antibodies to confirm their specificity.

All the antibodies used in the present study were tested for specificity. In the case of immunocytochemistry it was done by incubating the sections with the secondary antibody only, and for western blot the control of specificity was tested in the presence of the blocking peptide. Furthermore, the antibodies are commercially available, their specificity are warranted by the manufacturer as well as they have been tested by other authors [19-21].

\section{Statistical analysis}

Results were analyzed by unpaired Student's T test accessed through GraphPad Prism (GraphPad Software Inc., version $4.00, \mathrm{CA})$. A p-value $\leq 0.05$ was considered to indicate statistically significant differences. Data are expressed as mean \pm standard deviation (SD).

\section{Results}

\section{Cell culture characterization}

Quantification of cell cultures from the locus coeruleus and substantia nigra showed that $53 \%$ and $44 \%$, respectively, of these cells expressed the enzyme tyrosine hydroxylase, essential for the synthesis of catecholamines (Table 1). Hippocampal cultures presented 53\% of neurons labeled by MAP2 antibody (Table 1). This reveals that the cultures were suitable for studying substantia nigra, locus coeruleus and hippocampus cells.

\section{Effect of Rotenone on cell viability}

Rotenone promoted cell death in a dose-dependent manner in cultures of hippocampus, substantia nigra

\section{Table 1 Cell culture characterization}

\begin{tabular}{lccc}
\hline & DAPI & TH or MAP2 & \% TH or MAP2 positive cells \\
\hline Locus coeruleus & 656 & 349 & 53.20 \\
Substantia nigra & 857 & 377 & 43.99 \\
Hippocampus & 1711 & 909 & 53.1
\end{tabular}

Quantification of the percentage of cells immunopositive to tyrosine hydroxylase (TH) or microtubule-associated protein 2 (MAP2, Hippocampus) in relation to the total number of cells, indicated by DAPI, in cells cultures of locus coeruleus, substantia nigra and hippocampus. Count was performed in 16 fields of each culture plate of a total of 4 plates per experiment. 

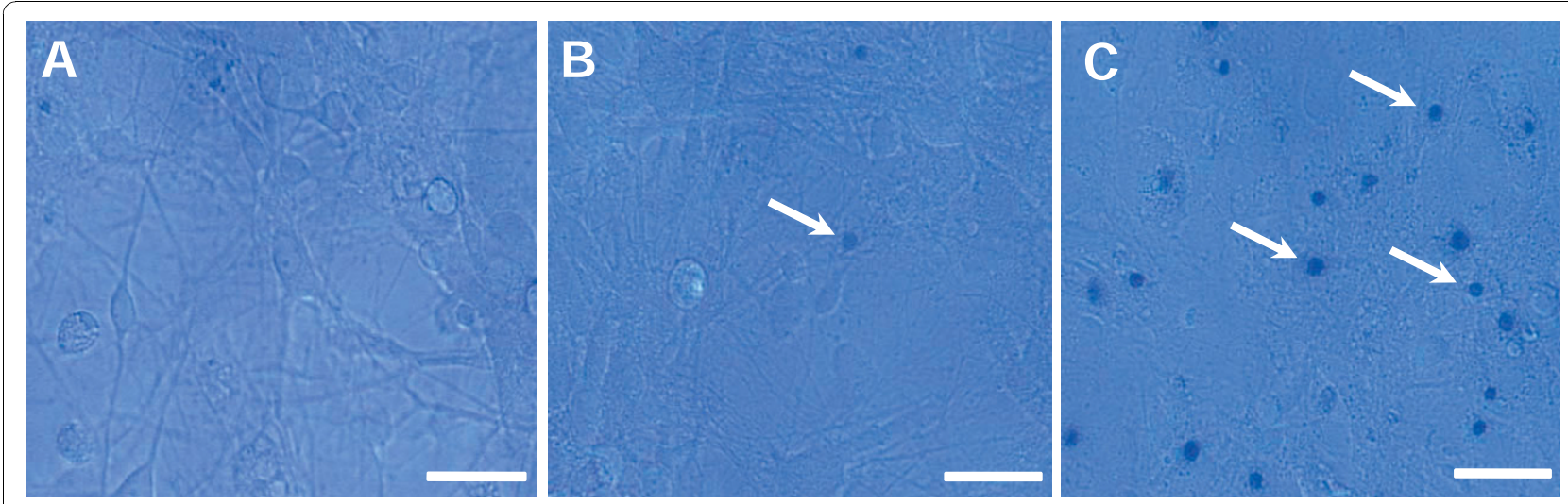

Figure 1 Analysis of rotenone toxicity. Photomicrographs illustrating the appearance of hippocampal cells treated with $0.5 \mathrm{nM}(\mathrm{A}), 1 \mathrm{nM}(\mathrm{B})$ and $10 \mathrm{nM}(\mathrm{C})$ of rotenone after addition of trypan blue in cell culture medium. Cells stained in blue (arrows) are under death process. Scale bar $=50 \mu \mathrm{m}$. Experiment was repeated three times. Cells from substantia nigra and locus coeruleus exhibited the same pattern of sensitivity.

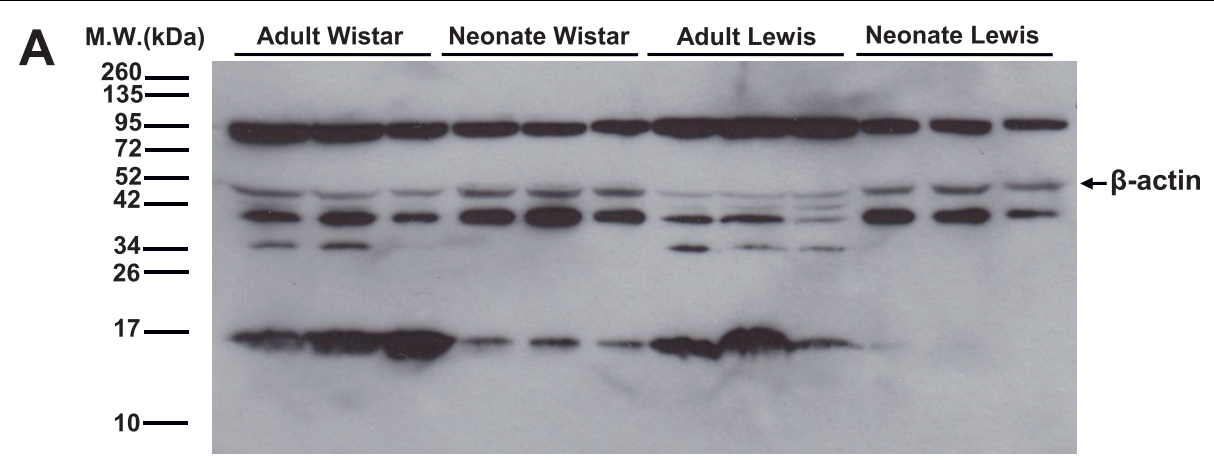

B M.W.(kDa)

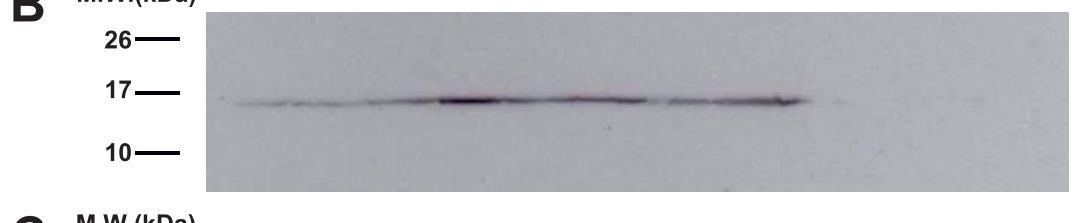

C M.W.(kDa)

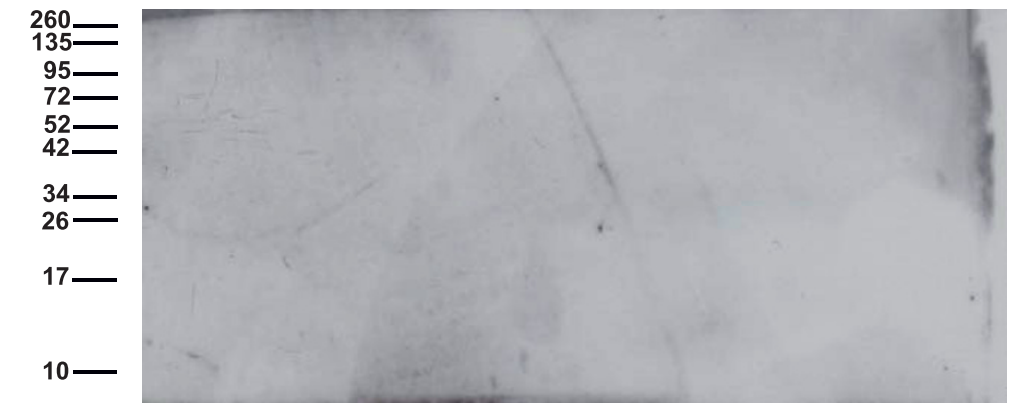

Figure 2 Alpha-synuclein isoforms. Western blot illustrating the isoforms of alpha-synuclein present in the substantia nigra of adult and newborn Wistar and Lewis rats using antibody from Abcam (A) and Santa Cruz (B), confirming the absence of the $14 \mathrm{kDa}$ isoform of alphasynuclein in neonate Lewis rats. The antibody from Abcam showed 3 isoforms of alpha-synuclein ( $90 \mathrm{kDa}, 40 \mathrm{kDa}$ and $14 \mathrm{kDa}$ ). Antibodies specificity was demonstrated by adding blocking peptide to the solution containing antibodies, which prevented the label of bands corresponding specifically to alpha-synuclein (C). 


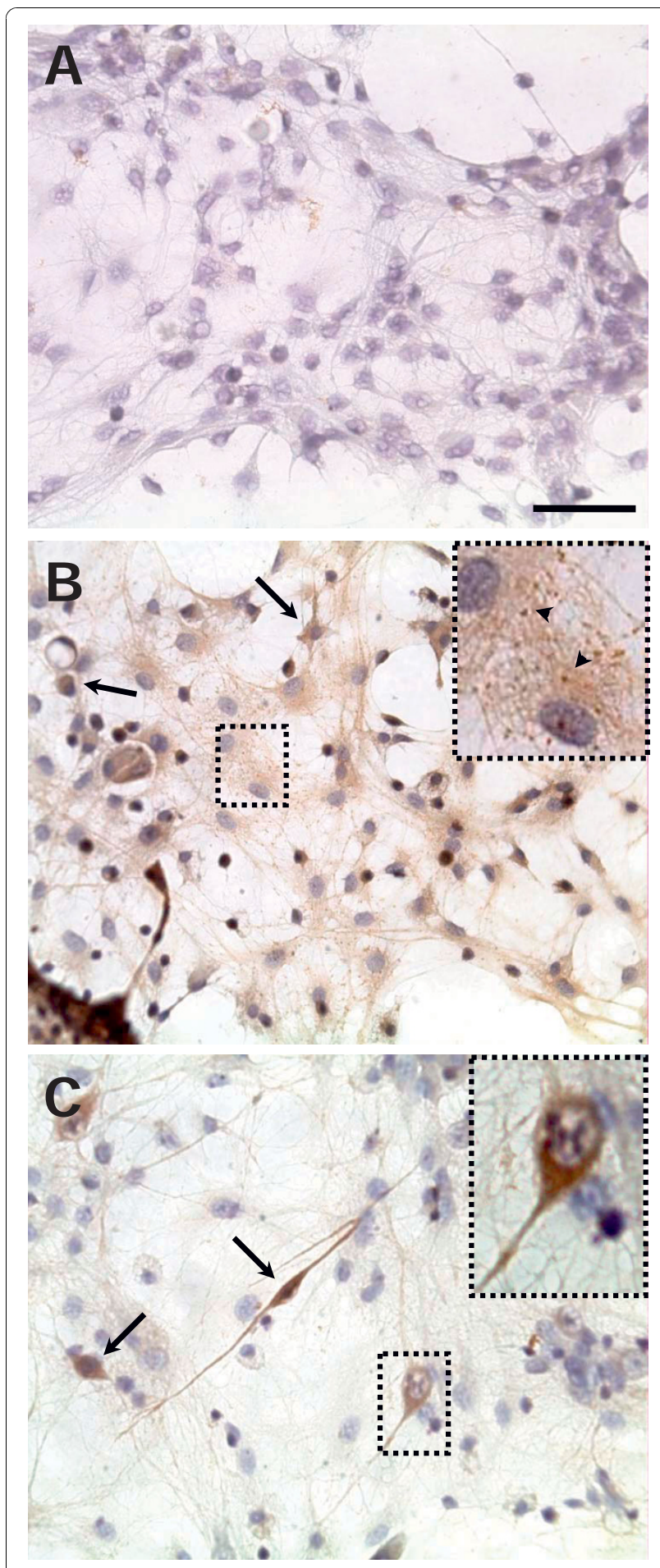

Figure 3 Aggregation of alpha-synuclein after rotenone exposure. Photomicrographs illustrating the immunoreactivity of alpha-synuclein in cultured cells of the locus coeruleus exposed to DMSO (A) or $0.5 \mathrm{nM}$ rotenone (B) and hippocampal cells exposed to $1 \mathrm{nM}$ of rotenone (C) for 48 hours. Arrows indicate cells with dense cytoplasm aggregates of alpha-synuclein. Arrowheads indicate sites of alpha-synuclein aggregation (detail in B). Cells were counterstained with hematoxylin (purple) after immunoreaction. Scale bar $=50 \mu \mathrm{m}$.

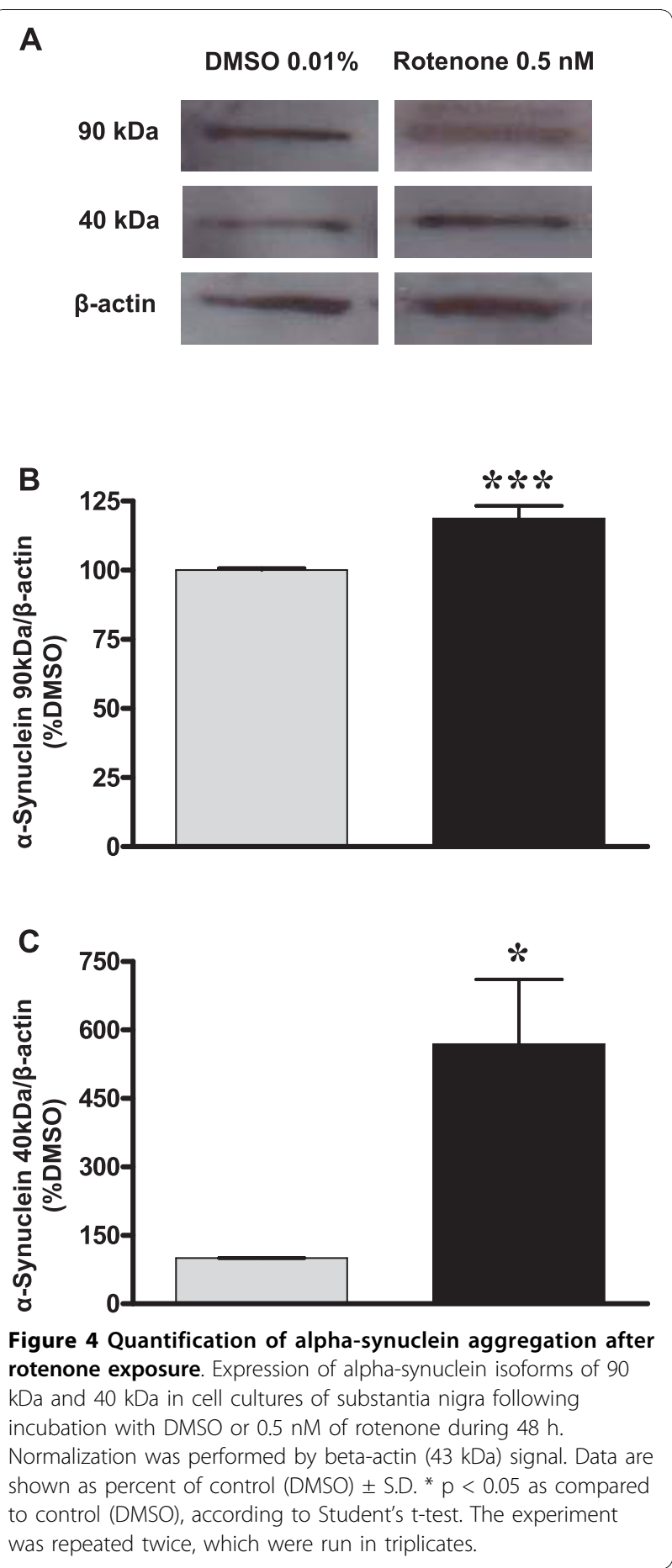

and locus coeruleus. Rotenone at $0.5 \mathrm{nM}$ seems not to be toxic to the hippocampal cells (Figure 1A). Incubation with $1 \mathrm{nM}$ of rotenone during $48 \mathrm{~h}$ stained a few cells in blue (Figure 1B), however $10 \mathrm{nM}$ of rotenone promoted a massive cell staining with trypan blue (Figure 1C). Cell cultures from substantia nigra and locus coeruleus exhibited the same pattern of sensitivity of hippocampal cells (data not shown). 


\section{Presence of alpha-synuclein isoforms in newborn Lewis rats}

The presence of alpha-synuclein isoforms was analyzed in newborn and adult Wistar and Lewis rats because during pilot experiments the $14 \mathrm{kDa}$ isoform never appeared in cultured cells from newborn Lewis rats. Figure 2A shows the pattern of isoforms labeling in newborn and adult rats from Wistar and Lewis strains using the antibody from Abcam. This confirms the absence of $14 \mathrm{kDa}$ isoform in neonate Lewis rats and its presence in neonatal Wistar and adult rats of both strains. The isoforms of $40 \mathrm{kDa}$ and $90 \mathrm{kDa}$ are present in all ages and strains. Adult rats showed an additional band of $34 \mathrm{kDa}$ (Figure 2A).

The same pattern of alpha-synuclein isoforms labeling was observed in neonate and adult rats when the antibody from santa cruz was employed (Figure 2B). The specificity of antibodies was demonstrated by the absence of labeling when incubating the antibodies with blocking peptide (Figure 2C).

\section{Alpha-synuclein protein aggregates}

Immunocytochemical staining using anti-alpha-synuclein antibody revealed that rotenone at $0.5 \mathrm{nM}$ or $1 \mathrm{nM}$ promoted aggregation of alpha-synuclein in cell bodies and extensions of the locus coeruleus and hippocampus as compared to DMSO-exposed cells (Figure 3). Besides the protein aggregation, exposure of hippocampal cells to $1 \mathrm{nM}$ of rotenone promoted apparent retraction of neuronal processes as well as reduced the total number of cells.
Western blot experiments were conducted to confirm and quantify alpha-synuclein aggregation in substantia nigra cells. In that assay there were two specific bands corresponding to alpha-synuclein one of $90 \mathrm{kDa}$ and another of $40 \mathrm{kDa}$, which were up-regulated by $25 \%$ and $400 \%$, respectively, following $0.5 \mathrm{nM}$ of rotenone as compared to DMSO-exposed cells (Figure 4).

\section{Hyperphosphorylation of tau}

Cells from the hippocampus were stained with antihyperphosphorylated tau antibody demonstrated that 0.5 $\mathrm{nM}$ of rotenone also promotes increase in hyperphosphorylation of tau protein in cell body and extensions (Figure 5). Densitometric analysis of the immunoblots corroborate with immunocytochemical experiments showing that isoforms of hiperphosphorylated tau of 52 and $130 \mathrm{kDa}$ increase their expression demonstrating possibly the hyperphosphorylated tau in hippocampal cells culture after exposure to $0.5 \mathrm{nM}$ of rotenone for 48 hours (Figure 6). The $230 \mathrm{kDa}$ isoform showed an unexpected significant decrease in expression, which may reveal that, at this level of hyperphosphorylation, tau is not aggregated yet.

\section{Identification of beta-amyloid protein aggregates}

The analysis of beta-amyloid aggregation was done by immunocytochemistry which demonstrates that the exposure to $1 \mathrm{nM}$ of rotenone was effective in developing protein aggregates containing that peptide as compared to cells exposed to DMSO (Figures 7A and 7B). Higher concentrations of rotenone (10 and $25 \mathrm{nM}$ )
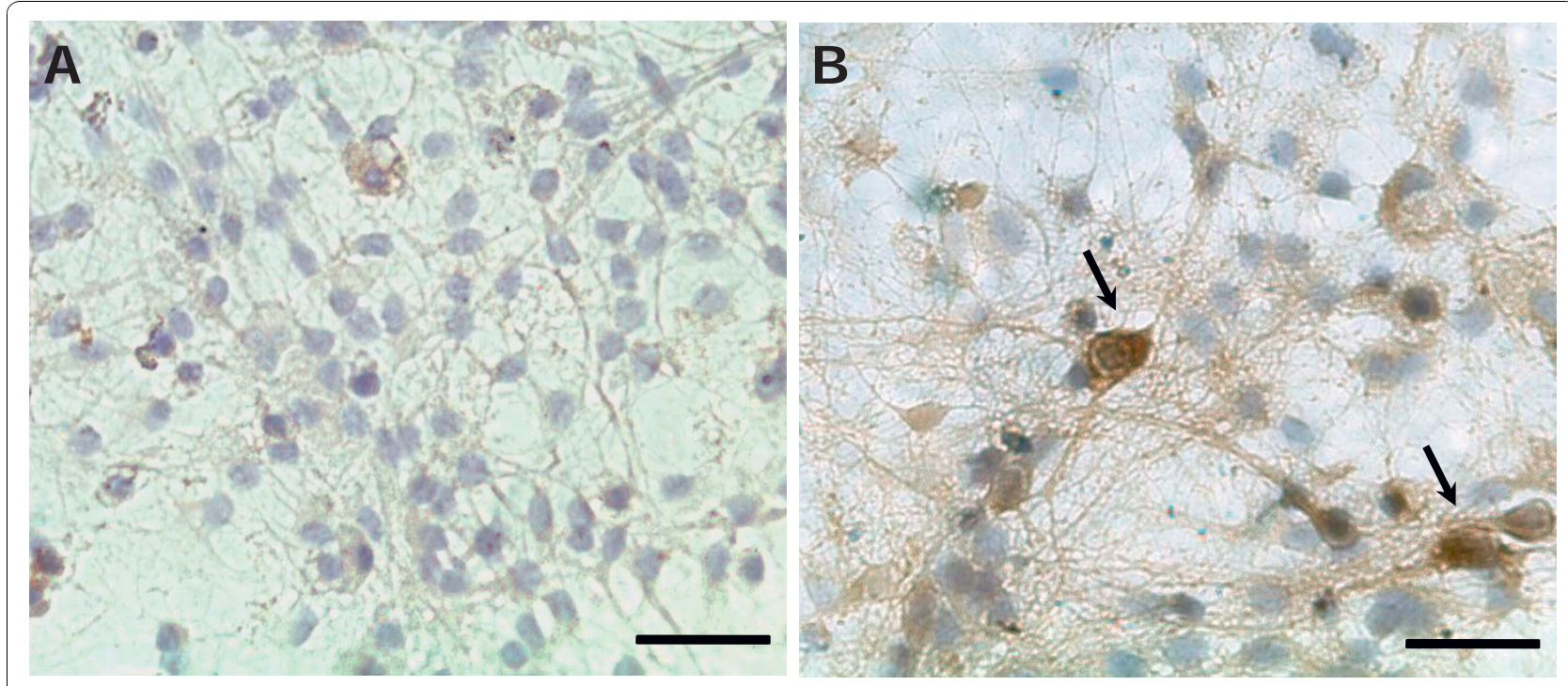

Figure 5 Increased hyperphosphorylation of tau after rotenone exposure. Photomicrographs illustrating the immunoreactivity of hyperphosphorylated tau in cultured cells of hipoccampus exposed to DMSO (A) or $0.5 \mathrm{nM}$ of rotenone (B) for 48 hours. Arrows indicate sites of hyperphosphorylated tau, possibly aggregated, distributed throughout cytoplasm and neurites. Scale bar $=50 \mu \mathrm{m}$. 
promoted nuclear retraction and fragmentation, as well as decrease in cell extensions (Figures 7C and 7D) demonstrating that high concentrations of the pesticide probably leads cells to death before the aggregation of beta-amyloid.

Quantification of area occupied by beta-amyloid imunopositive aggregates showed a significant increase after exposure to $0.5 \mathrm{nM}$ of rotenone for 48 hours (13.12 \pm $1.12)$ as compared to the control (2.39 \pm 0.43$)$ (Figure 8).

\section{Discussion}

To our knowledge this is the first report of in vitro protein aggregation promoted by the inhibition of mitochondrial respiratory chain complex I, these findings are of special interest for studying proteins involved in neurodegeneration such as alpha-synuclein, hyperphosphorylated tau and beta-amyloid.

High concentrations of rotenone (over $1 \mathrm{nM}$ ) lead to cell death prior to protein aggregation as demonstrated by trypan blue stain and amyloid beta immunocytochemistry independently of the region studied. Rotenone is an inhibitory drug of the mitochondrial respiratory chain complex I. However, low concentration of this compound $(0.5$ and $1 \mathrm{nM})$ is able to promote constitutive protein aggregation.

Many studies have employed in vivo and in vitro models to evaluate the neurodegeneration process. These models of neurodegeneration may involve the use of drugs such as 6-hydroxydopamine (6-OHDA), 1-methyl4-phenyl-1,2,3,6-tetrahydropyridine (MPTP) and rotenone [22], or overexpression of mutant genes in rats, mice and cell lineages [23-26]. Although these models are relevant to understand some aspects involved neurodegeneration, there is still lack of information about the events that cause constitutive protein aggregation and its role during the neurodegenerative processes. Recently De-Paula and colleagues [27] described that the inhibition of phospholipase A2 led to hyperphosphorylation of tau in primary cell culture, but the aggregation of other proteins such as alpha-synuclein and beta amyloid was not analyzed.

The use of primary cell culture, including neurons and glia, approximates the in vitro model and the physiological situation encountered in the brain. Recent evidences showed that dopaminergic death may be preceded by glial disfunction [28,29], as well as the interaction between neurons and astrocytes is of relevance to the course of neurodegeneration [30]. In view of this, we believe that the model using neurons and glial cells are more related to the real neuropathology than studying purified cell cultures.

The present study demonstrate that there is protein aggregation in condition of mitochondrial stress and proteasome inhibition which is a common feature
A

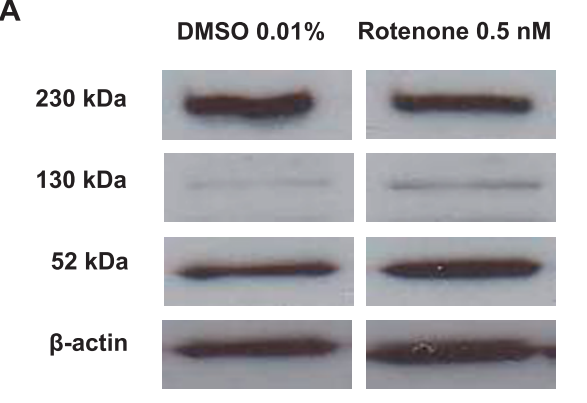

B
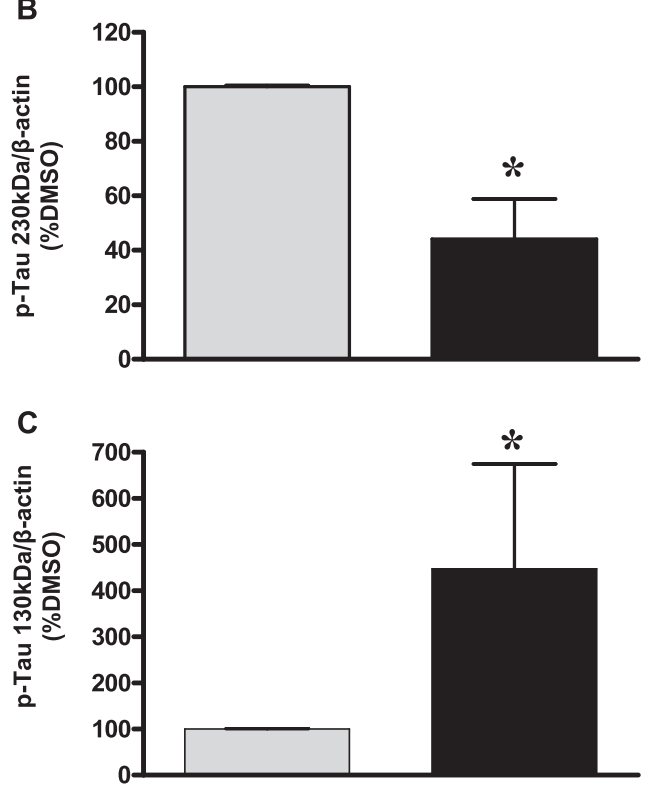

D

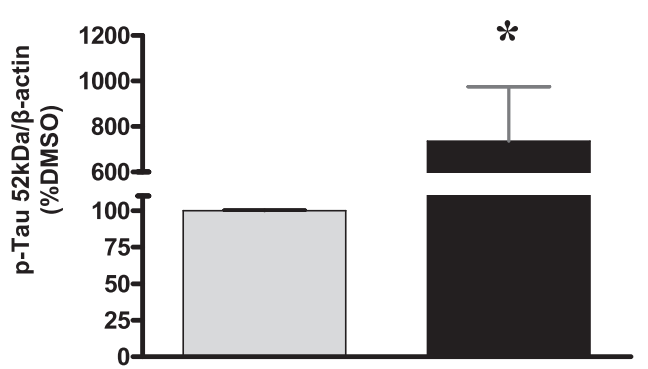

Figure 6 Quantification of hyperphosphorylated tau after rotenone exposure. Illustrative images of the pattern of bands corresponding to hyperphosphorylated tau in hippocampal cells exposed to $0.5 \mathrm{nM}$ of rotenone or DMSO for 48 hours (A). The 230 $\mathrm{kDa}$ bands are considered the insoluble fraction of hyperphosphorylated tau, which seems to be reduced after rotenone (B), the $130 \mathrm{kDa}$ bands are considered as oligomers of hyperphosphorylated tau (C) and 52-kDa bands as monomers of hyperphosphorylated tau (D), which are increased after prolonged exposure to low concentration of rotenone. Normalization was performed by beta-actin $(43 \mathrm{kDa})$ signal. Values are shown as percentage of control (DMSO) \pm S.D. ${ }^{*} p<0.05$ as compared to control (DMSO), according to Student's t-test. The experiment was repeated twice, which were run in triplicates. 


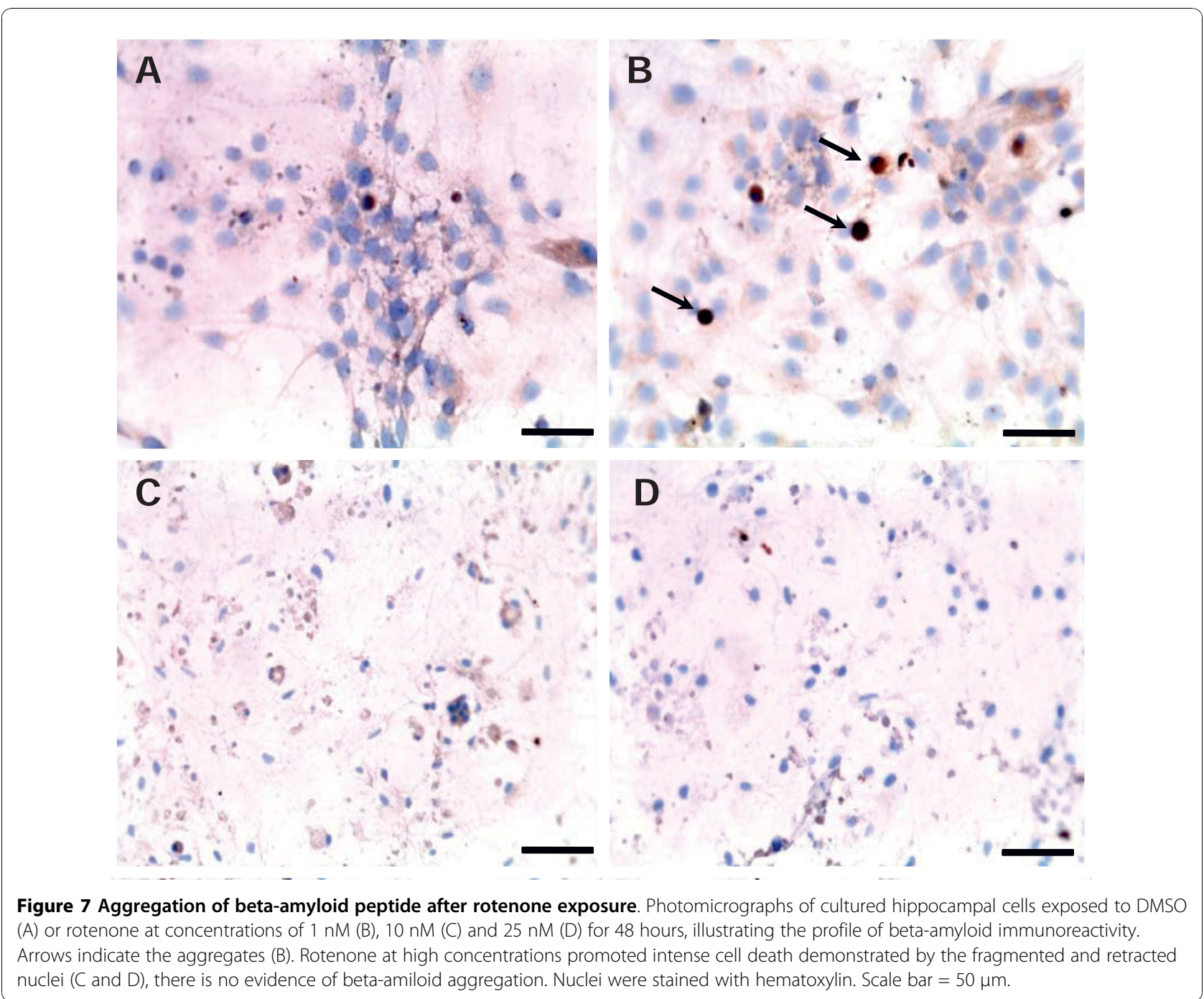

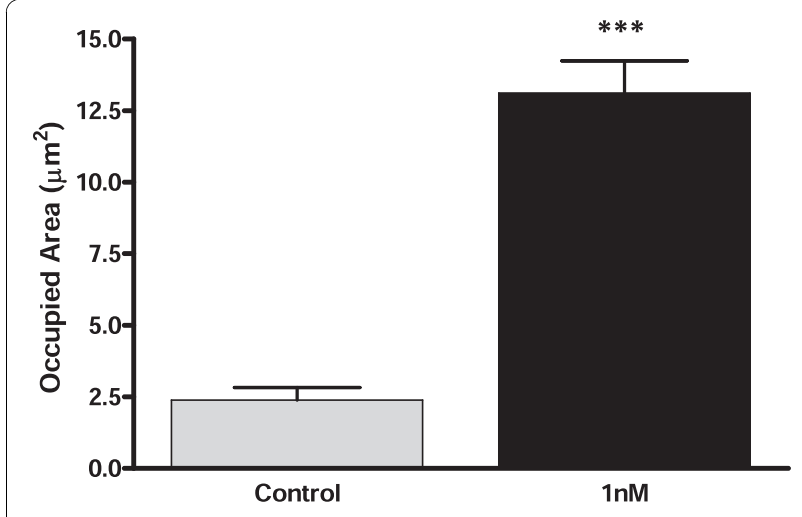

Figure 8 Quantification of beta-amyloid aggregation after rotenone exposure. Area occupied by beta-amyloid

immunopositive aggregates in hippocampal cells exposed to $1 \mathrm{nM}$ of rotenone during $48 \mathrm{~h}$. Values are shown as mean $\pm \mathrm{SD}{ }^{* *} \mathrm{p}<$ 0.0001 as compared to control cells (culture medium) from the same strain according to Student's t-test. The experiment was repeated twice. encountered during aging [31]. Thus, our model has some advantages over the genetic and transfection models since the aggregation is mainly sporadic and formed by constitutive proteins, similar to what occurs during ageing and neurodegeneration.

To validate our study we performed an assay to characterize the presence of alpha-synuclein in neonatal and adult rats. In this study we demonstrated that the isoform of $14 \mathrm{kDa}$ of alpha-synuclein, which is the most studied isoform of this protein, is not present in neonatal Lewis rats but is expressed in the adult age. Since cultures were made using newborn Lewis rats there was not label of the $14 \mathrm{kDa}$ isoform alpha-synuclein in aggregation studies. The use of Lewis rats in our experiments was important because of their exclusive susceptibility to form protein aggregates after treatment with rotenone in in vivo experiments $[32,33]$.

Rotenone was able to induce alpha-synuclein aggregation, which is of interest for studying neurodegeneration 
associated to protein aggregation. Not only the aggregation itself is related to neurodegeneration, the imbalance of neurotransmission may trigger neurodegenerative mechanisms, evidences indicate that alpha-synuclein is encountered in association with the presynaptic vesicle pool [34] and the aberrant association between alphasynuclein and rab proteins [35] may be of relevance in the study of cellular stress that leads to neurodegenarative disorders.

Hyperphosphorylation of tau protein is a condition that disrupts the intracellular trafficking impairing neurotransmission in association with formation of intracellular inclusion of paired helical filaments. In the present study we demonstrated that rotenone may be involved in hyperphosphorylation of tau protein as demonstrated by the increase in optical density of $52 \mathrm{kDa}$ subunit. The fraction of $130 \mathrm{kDa}$ is increased in rotenone-treated cells demonstrating a possible mechanism of aggregation that occurs in low concentrations of rotenone. The $130 \mathrm{kDa}$ band may correspond to small aggregates (dimerization/trimerization) of hyperphosphorylated tau, as previously demonstrated [36,37].The presence of tau hyperphosphorylated in control groups is apparently normal in neonatal rats and has been described by Goedert and colleagues [38].

Beta-amyloid plaques were found in cells from hippocampus after incubation during $48 \mathrm{~h}$ with rotenone. High concentrations of the drug is toxic leading to cell death before protein aggregation, which is devoid to the high toxicity. Furthermore, endogenous increase of amyloid beta peptide production preceeds hyperphosphorylation of tau [39], which may be of interest to evaluate the mechanism of protein aggregation.

Besides the well known effects of rotenone in inhibiting mitochondrial complex I, the pesticide is also able to impair protein degradation by interfering with the ubiquitin-proteasome-system [40], in view of this the aggregation seen in the present study may be also in response to the deficit of the cellular systems of protein degradation in addition to the increase in oxidative stress. Actually Branco and co-workers demonstrated the cross-talk between mitochondria and proteasome during the pathogenesis of Parkinson's disease [41]. The effect of rotenone over the impairment of the proteasome is being conducted as a parallel study in our laboratory.

\section{Conclusions}

In conclusion this study demonstrated a new method to study constitutive protein aggregation in vitro by the exposure of neonatal cultured cells of Lewis rats to low concentrations of rotenone, which may be of relevance to understand the mechanisms that lead to idiopathic neurodegeneration.

\section{Acknowledgements}

We thank Edilaine Tampellini Santos and Livia Polichiso for their support during antibodies standardizing for immunohistochemistry and identification of aggregates in rat cells. This study was supported by research grants from FAPESP (2008/04480-9) and CNPq (472042/2008-4). R.S.C., T.Q.M. and S.A.M. received fellowships from FAPESP (2008/04655-3; 2009/02345-0 and 2009/ 00010-0, respectively).

\section{Authors' contributions}

RSC carried out cell culture characterization, cell death assay, immunocytochemistry of alpha-synuclein and western blot experiments. TQM performed beta-amyloid immunocytochemistry in cultured cells made by herself. SAM carried out cell cultures and tau immunocytochemistry. MFRF conceived of the study, designed and coordinated the experiments. All authors analyzed the results, participated of manuscript draft, read and approved the final manuscript.

\section{Competing interests}

The authors declare that they have no competing interests.

Received: 18 June 2010 Accepted: 10 November 2010

Published: 10 November 2010

\section{References}

1. Ross CA, Poirier MA: Opinion: What is the role of protein aggregation in neurodegeneration? Nature reviews 2005, 6(11):891-898.

2. Dayan AD: Quantitative histological studies on the aged human brain. I. Senile plaques and neurofibrillary tangles in "normal" patients. Acta neuropathologica 1970, 16(2):85-94.

3. Jager W, Bethlem J: The distribution of Lewy bodies in the central and autonomic nervous systems in idiopathic paralysis agitans. J Neurol Neurosurg Psychiatry 1960, 23:283-290.

4. Ohama E, Ikuta F: Parkinson's disease: distribution of Lewy bodies and monoamine neuron system. Acta neuropathologica 1976, 34(4):311-319.

5. Oyanagi K, Wakabayashi K, Ohama E, Takeda S, Horikawa Y, Morita T, Ikuta F: Lewy bodies in the lower sacral parasympathetic neurons of a patient with Parkinson's disease. Acta neuropathologica 1990, 80(5):558-559.

6. Kakita A, Takahashi H, Homma Y, Ikuta F: Lewy bodies in the cerebellar dentate nucleus of a patient with Parkinson's disease. Pathology international 1994, 44(12):878-880

7. Wakabayashi K, Takahashi H: Neuropathology of autonomic nervous system in Parkinson's disease. Eur Neurol 1997, 38:2-7.

8. Takahashi RH, Nam EE, Edgar M, Gouras GK: Alzheimer beta-amyloid peptides: normal and abnormal localization. Histology and histopathology 2002, 17(1):239-246.

9. Bourgeat $P$, Chetelat $G$, Villemagne VL, Fripp J, Raniga P, Pike K, Acosta O, Szoeke C, Ourselin S, Ames D, et al: Beta-amyloid burden in the temporal neocortex is related to hippocampal atrophy in elderly subjects without dementia. Neurology 2010, 74(2):121-127.

10. Jellinger KA: Recent advances in our understanding of neurodegeneration. J Neural Transm 2009, 116(9):1111-1162.

11. Sherer TB, Kim JH, Betarbet $R$, Greenamyre JT: Subcutaneous rotenone exposure causes highly selective dopaminergic degeneration and alphasynuclein aggregation. Experimental neurology 2003, 179(1):9-16.

12. Dukes AA, Korwek KM, Hastings TG: The effect of endogenous dopamine in rotenone-induced toxicity in PC12 cells. Antioxidants \& redox signaling 2005, 7(5-6):630-638

13. Sherer $T B$, Betarbet $R$, Kim JH, Greenamyre JT: Selective microglial activation in the rat rotenone model of Parkinson's disease. Neuroscience letters 2003, 341(2):87-90.

14. Chou AP, Li S, Fitzmaurice AG, Bronstein JM: Mechanisms of rotenone-induced proteasome inhibition. Neurotoxicology 2010, 31(4):367-372.

15. Huang J, Hao L, Xiong N, Cao X, Liang Z, Sun S, Wang T: Involvement of glyceraldehyde-3-phosphate dehydrogenase in rotenone-induced cell apoptosis: relevance to protein misfolding and aggregation. Brain research 2009, 1279:1-8.

16. Silva JM, Wong A, Carelli V, Cortopassi GA: Inhibition of mitochondrial function induces an integrated stress response in oligodendroglia. Neurobiology of disease 2009, 34(2):357-365. 
17. Kivell BM, McDonald FJ, Miller $\mathrm{JH}$ : Method for serum-free culture of late fetal and early postnatal rat brainstem neurons. Brain research 2001, 6(3):91-99.

18. Zoli M, Zini I, Agnati L, Guidolin D, Ferraguti F, Fuxe K: Aspects of neuronal plasticity in the central nervous system. I. Computer-assisted image analysis methods. Neurochem Int 1990, 16:383-418.

19. Carrettiero DC, Hernandez I, Neveu P, Papagiannakopoulos T, Kosik KS: The cochaperone BAG2 sweeps paired helical filament- insoluble tau from the microtubule. J Neurosci 2009, 29(7):2151-2161.

20. Marksteiner J, Humpel C: Beta-amyloid expression, release and extracellular deposition in aged rat brain slices. Molecular psychiatry 2008, 13(10):939-952.

21. Vogiatzi T, Xilouri M, Vekrellis $K$, Stefanis L: Wild type alpha-synuclein is degraded by chaperone-mediated autophagy and macroautophagy in neuronal cells. The Journal of biological chemistry 2008, 283(35):23542-23556

22. Schmidt WJ, Alam M: Controversies on new animal models of Parkinson's disease pro and con: the rotenone model of Parkinson's disease (PD). Journal of neural transmission 2006, 70:273-276.

23. Gotz J, Streffer JR, David D, Schild A, Hoerndli F, Pennanen L, Kurosinski P, Chen F: Transgenic animal models of Alzheimer's disease and related disorders: histopathology, behavior and therapy. Molecular psychiatry 2004, 9(7):664-683.

24. Hattori N, Sato S: Animal models of Parkinson's disease: similarities and differences between the disease and models. Neuropathology 2007, 27(5):479-483.

25. Lee HJ, Shin SY, Choi C, Lee YH, Lee SJ: Formation and removal of alphasynuclein aggregates in cells exposed to mitochondrial inhibitors. The Journal of biological chemistry 2002, 277(7):5411-5417.

26. Schule B, Pera RA, Langston JW: Can cellular models revolutionize drug discovery in Parkinson's disease? Biochim Biophys Acta 2009, 1792(11):1043-1051.

27. De-Paula VJ, Schaeffer EL, Talib LL, Gattaz WF, Forlenza OV: Inhibition of phospholipase A2 increases tau phosphorylation at Ser214 in embryonic rat hippocampal neurons. Prostaglandins, leukotrienes, and essential fatty acids 2010, 82(1):57-60.

28. Hirsch EC, Hunot S: Neuroinflammation in Parkinson's disease: a target for neuroprotection? Lancet neurology 2009, 8(4):382-397.

29. Tansey MG, Goldberg MS: Neuroinflammation in Parkinson's disease: its role in neuronal death and implications for therapeutic intervention. Neurobiology of disease 2010, 37(3):510-518.

30. Mullett SJ, Hinkle DA: DJ-1 knock-down in astrocytes impairs astrocytemediated neuroprotection against rotenone. Neurobiology of disease 2009, 33(1):28-36.

31. Boveris $A$, Navarro $A$ : Brain mitochondrial dysfunction in aging. IUBMB Life 2008, 60(5):308-314.

32. Testa CM, Sherer TB, Greenamyre JT: Rotenone induces oxidative stress and dopaminergic neuron damage in organotypic substantia nigra cultures. Molecular Brain Research 2005, 134(1):109-118.

33. Sherer TB, Betarbet R, Testa CM, Seo BB, Richardson JR, Kim JH, Miller GW, Yagi T, Matsuno-Yagi A, Greenamyre JT: Mechanism of toxicity in rotenone models of Parkinson's disease. J Neurosci 2003, 23(34):10756-10764.

34. Murphy DD, Rueter SM, Trojanowski JQ, Lee VM: Synucleins are developmentally expressed, and alpha-synuclein regulates the size of the presynaptic vesicular pool in primary hippocampal neurons. J Neurosci 2000, 20(9):3214-3220.

35. Dalfo E, Barrachina M, Rosa JL, Ambrosio S, Ferrer I: Abnormal alphasynuclein interactions with rab3a and rabphilin in diffuse Lewy body disease. Neurobiology of disease 2004, 16(1):92-97.

36. Blard O, Frebourg T, Campion D, Lecourtois M: Inhibition of proteasome and Shaggy/Glycogen synthase kinase-3beta kinase prevents clearance of phosphorylated tau in Drosophila. Journal of neuroscience research 2006, 84(5):1107-1115.

37. Shelton SB, Johnson GV: Tau and HMW tau phosphorylation and compartmentalization in apoptotic neuronal PC12 cells. Journal of neuroscience research 2001, 66(2):203-213.

38. Goedert $M$, Jakes $R$, Crowther RA, Six J, Lubke U, Vandermeeren M, Cras P, Trojanowski JQ, Lee VM: The abnormal phosphorylation of tau protein at Ser-202 in Alzheimer disease recapitulates phosphorylation during development. Proceedings of the National Academy of Sciences of the United States of America 1993, 90(11):5066-5070.

39. Amadoro G, Corsetti V, Ciotti MT, Florenzano F, Capsoni S, Amato G, Calissano P: Endogenous Abeta causes cell death via early tau hyperphosphorylation. Neurobiol Aging 2009.

40. Wang XF, Li S, Chou AP, Bronstein JM: Inhibitory effects of pesticides on proteasome activity: implication in Parkinson's disease. Neurobiology of disease 2006, 23(1):198-205.

41. Branco DM, Arduino DM, Esteves AR, Silva DF, Cardoso SM, Oliveira CR: Cross-talk between mitochondria and proteasome in Parkinson's disease pathogenesis. Frontiers in aging neuroscience 2010, 2:17.

doi:10.1186/1471-2202-11-144

Cite this article as: Chaves et al.: Protein aggregation containing betaamyloid, alpha-synuclein and hyperphosphorylated tau in cultured cells of hippocampus, substantia nigra and locus coeruleus after rotenone exposure. BMC Neuroscience 2010 11:144.

\section{Submit your next manuscript to BioMed Central and take full advantage of:}

- Convenient online submission

- Thorough peer review

- No space constraints or color figure charges

- Immediate publication on acceptance

- Inclusion in PubMed, CAS, Scopus and Google Scholar

- Research which is freely available for redistribution

Submit your manuscript at www.biomedcentral.com/submit
Biomed Central 